Revue et Magasin de Zoologie. Par M. F. E. Gú́rin-Méneville. $2^{\mathrm{e}}$ sér. vol. iv. no. 1. Janvier 1852.

This periodical, which is devoted to the various branches of pure and applied zoology, including palæontology and comparative anatomy, is published monthly in Paris. It is divided into three sections : the first contains original articles, the second reports of the proceedings of the Parisian learned societies, and the third consists of analyses of new works.

Of these three sections the first is the most important, from its containing many descriptions of new species of animals; and as the work possesses only a limited circulation in this country, and many of these descriptions are consequently liable to be quite unknown to the English naturalist, we propose to furnish our readers from time to time with an analysis of the contents of this portion of the work, giving, as far as possible within moderate limits, the diagnostic characters of any new animals described, with analyses of any original anatomical or physiological papers which may appear in the magazine.

The number for January 1852 contains-

I. Descriptions of some new species of Birds, by Dr. G. Hartlaub (pp. 1-7). These birds are ten in number, namely, 1. Strix thomensis, an inhabitant of the tropical African island of St. Thomas; 2. Zonotrichia mysticalis, from Mexico; 3. Formicivora erythronotos, from Brazil, a species in form and size resembling $F$. axillaris, Vieill.; 4. Thryothorus murinus, from Mexico; 5. Setophaga intermedia, a species inhabiting Guatemala, intermediate between S. vulnerata and S. verticalis; 6. Dromolaa incompta (Saxicola incompta, Licht. MS. in Mus. Brem.), from Caffraria; 7. Tyrannula rufula, from Brazil ; 8. Picus Kaupii, from Chili ; 9. Cypselus Abyssinicus, Streubel ; and 10. Anser Gambelli, a species from Texas, nearly allied to A. albifrons, Hartl.

II. Descriptions of six new Birds belonging to the Collection of the Museum of Natural History at Paris, by P. L. Sclater (pp. 8, 9). Five of these species are from New Grenada; the sixth is without indication of locality. The following are the characters of these birds given by Mr. Sclater :-

1. Arremon mysticalis. A. supra olivaceus, pennis caudaque nigris olivaceo limbatis; pileo rufo : fronte et capitis collique lateribus cum gula, nisi media, atris ; mento, gula media et linea a basi rostri ad collum utrinque descendente albidis; abdomine crissoque flavis, lateribus olivascentibus; rostro nigro, pedibus corneis. Total length $6 \frac{1}{4}$ inches ; wings $3 \frac{7}{8}$ in.

2. Pipilopsis flavigularis. P. supra olivacea, pennis caudaque nigris olivaceo limbatis : infra abdomine toto cum mento cinereis, gutture flavo, crisso flavescente; rostro plumbeo, basi albo notato; pedibus plumbeis; ventre medio albescentiore. Total length $5 \frac{1}{2}$ in.; wings $3 \frac{1}{4}$ in.

3. Pipraidea albiventris. P. supra cærulea, pennis nigris, anguste cæruleo marginatis ; cauda nigra ; ventre crissoque albis ; rostro pedibusque nigris. Total length $3 \frac{1}{4}$ in.; wings $2 \frac{1}{8}$ in. 
4. Pipra Isidorei. P. atra; capite albo; uropygio cyaneo. Tota length 3 in.; wings $1 \frac{7}{8}$ in.

5. Pipra flavicapilla. P. flavo-olivacea, remigibus rectricibusque nigricantibus olivaceo limbatis ; capite toto cum cervice supra aurantio-flavo; subtus aureo-flava gutture et cervicis lateribus olivaceotinctis ; pedibus nigricantibus ; rostro plumbeo. Total length $4 \frac{1}{2}$ in.; wings 3 in.; tail $1 \frac{3}{4}$ in.

6. Pipra pyrocephala. P. roseo-brunnea; subtus dilutior, leviter saturatiore striata; alis et lateribus cervicis olivaceis ; remigibus et rectricibus nigricantibus ; capite supra flavo, vertice medio ruberrimo; rostro nigricante, pedibus albescentibus. Total length $3 \frac{1}{4}$ in; wings $2 \frac{1}{4}$ in.

III. Description of a new species of the genus Argonauta, by M. E. L. Lorois (p. 9).

This species of Argonauta is dedicated by its describer to the gentleman who brought it from the Pacific, M. Noury, the captain of a French frigate. It is characterized as follows :-

Argonauta Nouryi. Testa parvula, involuta, elongata, tenui, translucida, albido-grisea, rugis lateribus undulatis, spira tantum carinata, tuberculis carinarum nigris, minimis, linea alba separatis, ultimo anfractu subrotundato, ad spiræ carinarum prolongationem paulisper depresso. Long. 58 mill.; larg. 35 mill.

It is figured in the plate accompanying the number.

IV. Catalogue of the Molluscous animals inhabiting the coast of the "Charente-Inférieure," by M. Henri Aucapitaine (pp. 10-21).

This catalogue includes 164 species, belonging to 75 genera; it is accompanied by a few notes relative to some of the species.

V. Descriptions of four new and remarkable Coleopterous insects, by M. Reiche (pp. 21-25).

This paper consists of descriptions of four Lamellicorn beetles, three of them of rather large size. They are nicely figured in outline in the plate accompanying the part. The first,

1. Democrates Burmeisteri, differs from the type of the genus, D. Crosus, Newm., in its smaller size, the blackish tint of its head and thorax, and in the punctuation of the elytra. It is from Quito.

2. Megalosoma Mars. This insect is very nearly allied to $M$. Actaon. It is from tropical America, about the Rio Negro.

3. Anoplocnemus Dejeanii; probably an inhabitant of the East Indies.

4. Anoplocnemus Lafertei, a fine species from Australia, which M. Reiche thinks may probably form the type of a new generic group characterized by its exposed eyes, the straightness of its mandibles, and the form of its thorax.

The remainder of the number is occupied by reports of the sittings of the 'Académie des Sciences' of the 5th and 12th of January 1852, and notices of two or three new works. 


\section{In the Press.}

Prodromus Fauna. Zeylanica, being Contributions to the Zoology of Ceylon. By Ed. Fred. KelaArt, M.D., F.L.S., Staff-Surgeon, \&c.

We have much pleasure in drawing attention to this work: the fauna of Ceylon has always been classed among the richest in the world; but till within the last few years very little of it was known to the systematic naturalist. Dr. Kelaart's work will contain a familiar and a technical description of all the known Ceylon quadrupeds and other animals of the class Mammalia (upwards of eighty in number). The work will also contain a systematically arranged catalogue (with English names) of more than 200 Ceylon birds, and a descriptive account of all the known Chelonian, Saurian, and Batrachian reptiles; to which will be added an Appendix replete with information on other branches of the zoology of the island. On the whole, this work (Prodromus Faunæ Zeylanicæ) will contain the fullest and most recent information on the extensive and beautiful fauna of Ceylon.

\section{PROCEEDINGS OF LEARNED SOCIETIES.}

\section{ZOOLOGICAL SOCIETY.}

Jan. 14, 1851.-Prof. Owen, F.R.S., Vice President, in the Chair. The following papers were read:-

\section{ON A NEW AND MOST REMARKABLE FORM IN ORNithology. By JoHn Gould, F.R.S. ETc.}

I have the pleasure of introducing to the notice of the Society on the present occasion the most extraordinary bird I have seen for many years, and which forms part of a collection made on the banks of the upper part of the White Nile, by Mansfield Parkyns, Esq., of Nottingham. For this bird I propose the generic name of BALeNICEPS, with the following characters :-

Bill enormously robust, equal in breadth and depth; sides of the upper mandible much swollen; culmen slightly elevated, depressed in the middle of its length, and terminating at the point in a very powerful hook; tomiæ sharp, turning inwards and very convex; lower mandible very powerful, with a sharp concave cutting edge and a truncated tip; nostrils scarcely perceptible, and placed in a narrow slit at the base of the bill, close to the culmen; orbits denuded; head very large; occiput slightly crested; wings very powerful, the third, fourth and fifth feathers the longest; tail of moderate length and square in form; plumage soft and yielding; skin of the throat loose, and capable of dilatation into an extensive pouch; tibiæ and tarsi lengthened, the latter a fourth shorter than the former; the lower third of the tibiæ denuded ; toes four in number, all extremely long, and without the slightest vestige of interdigital membrane; hind-toe on the same plane as the anterior ones and directed inwards; tibiæ and tarsi reticulated, the reticulations becoming much smaller 


\section{$2 \mathrm{BHL}$ Biodiversity Heritage Library}

1852. "Revue et Magasin de Zoologie. Par M. F. E. Guérin-Méneville. 2e sér. vol. iv. no. 1. Janvier 1852." The Annals and magazine of natural history; zoology, botany, and geology 10, 364-366. https://doi.org/10.1080/03745485609495720.

View This Item Online: $\underline{\text { https://www.biodiversitylibrary.org/item/19400 }}$

DOI: https://doi.org/10.1080/03745485609495720

Permalink: https://www.biodiversitylibrary.org/partpdf/10733

\section{Holding Institution}

Natural History Museum Library, London

\section{Sponsored by}

Natural History Museum Library, London

\section{Copyright \& Reuse}

Copyright Status: Public domain. The BHL considers that this work is no longer under copyright protection.

This document was created from content at the Biodiversity Heritage Library, the world's largest open access digital library for biodiversity literature and archives. Visit BHL at https://www.biodiversitylibrary.org. 